\title{
Main Components of Protecting Consumers of Financial Prod- ucts in Asian-Oceanic (APAC) Countries
}

\author{
Elena Petrovna Ermakova', Ekaterina Petrovna Rusakova ${ }^{1}$, Elena Vitalievna Sitkareva1, Evgenia Evgenevna Frolo- \\ va
}

${ }^{1}$ Peoples' Friendship University of Russia (RUDN University), Miklukho-Maklaya Street, 6, Moscow, 117198, Russia

\begin{abstract}
The article offers a general overview of basic components on protecting rights of consumers of financial products in the APAC countries, including 1) special legislation, 2) special (nonjudicial) authorities on resolving financial disputes, and 3) training population. After all, the focus was made on analyzing the protection of rights of consumers of financial products in four APAC countries - the USA, Malaysia, New Zealand and Singapore - in order to show tendencies and the best practices of each country under analysis.
\end{abstract}

Keywords: financial sector, financial products, protection of consumers' rights, Financial Ombudsman Service, APAC countries, USA, Malaysia, New Zealand, Singapore.

\section{Introduction}

The financial system is the basis of the welfare and prosperity of any state in the world. The financial system covers a wide range of institutions that can be combined into the following groups: 1) depository system (banks, savings associations and thrift institutions), 2) financial markets, 3) assets management and insurance industries, as well as investment products, and 4) nonbank financial institutions. All institutions of the financial system provide financial services. Financial services are financial intermediation services, as a rule, loans. The unusual phrase "financial products" means packages of interrelated financial services of financial instruments and technologies offered by financial institutions on the financial market as a commodity. Financial products are classified by financial activities: bank, insurance, pension, and investment products. The most popular financial products are stocks, bonds, investment funds, warrants and options.

Ensuring a high level of protecting consumers of financial products is one of the indicators of successful financial system of the state $[1,2]$.

As a rule, the issue about the consumers' protection is touched upon during global financial crises. This happened in the USA when in 1933, after the riots related to closing banks, the Federal Deposit Insurance Corporation (FDIC) was established to provide the general public with a guarantee that individual savings will not disappear when the bank becomes a bankrupt.

Like in case of purchasing ordinary goods, when buying financial products and services, buyers (ordinary citizens) and sellers (banks and financial institutions) also suffer disputes. It was revealed that in the Asian-Oceanic countries in most cases financial disputes were considered not by state courts, but, alternatively, by the Financial Ombudsman Service, the Banking Ombudsman, and the Financial Mediation Bureau. Some authorities on alternative resolution of financial disputes have been recognized worldwide. The conducted study revealed that the main components of protecting rights of consumers in the Asian-Oceanic countries includ- ed: 1) special legislation on protecting the rights of financial services consumers, 2) special (nonjudicial) authorities on resolving financial disputes, and 3) training population and promoting the protection of rights of financial services consumers.

\section{Methods}

The APAC countries were selected for the study due to their role and importance in the area of improving consumer protection. The USA have an honorable authority in the area of legal regulation, propaganda and training of the population to protect their financial rights, as well as alternative settlement of financial disputes. The Financial Industry Regulatory Authority (FINRA), the American agency, is one of the first in the list of nongovernmental organizations that provide arbitration and mediation services for financial disputes. This was reported, in particular, by specialists of Mayer Brown, the well-known audit firm, et al. [3, 4]. Many foreign analysts put Singapore Financial Industry Disputes Resolution Centre Ltd (FIDReC) on the second place. It started its operation in 2005. After the 2008 global financial crisis, modern comprehensive consumer protection legislation was created in the USA, as well as in Malaysia and New Zealand, which predetermined this article authors' interest in these countries.

\section{Results}

\subsection{Special Legislation to Protect Rights of Consumers of Financial Services}

\subsubsection{USA}

The policy of the US government in relation to consumer protection is based on the notion that consumers should have the right to protect their own interests. That is why the USA focus on ensuring that sellers provide full information about their products to allow consumers to make a conscious choice and provide access to jus- 
tice, including through class actions and collective actions [5]. The USA have formed a coherent system for protecting rights of financial services consumers. It allows the consumer to use both quasijudicial administrative procedures and services of the ombudsman of the Consumer Financial Protection Bureau (CFPB). The activities of these authorities are regulated by relevant normative acts, including laws - the 1946 Administrative Procedure Act and internal regulation such as the Rules of Practice for Adjudication Proceedings or the Ombudsman's Office Charter.

The Federal Trade Commission (FTC) is a specialized government authority for the protection of consumer rights [6]. The FTC powers are based on Article 5 (a) of the Federal Trade Commission Act of 1914 that prohibits "unfair or deceptive actions or practices affecting trade". The FTC powers in the finances are defined in a number of US normative acts related to loans: 1) the Truth in Lending Act of 1968, 2) the Fair Credit Billing Act of 1974, 3) the Fair Credit Reporting Act of 1970, and 4) the Equal Credit Opportunity Act of 1974. In addition, the USA adopted the laws relating to the consumers' privacy such as the Do-Not-Call Registry Act of 2003, and the Non Solicited Pornography and Marketing Act 2003 - CAN-SPAM of 2003.

As a whole, the regulation of the US financial system is extremely complex and multilevel. The structure and powers of the main financial regulators were affected by the 2008 financial crisis These changes were reflected in the Dodd-Frank Act of 2009 According to the provisions of this law, the CFPB [7] was established. Some financial regulators were abolished: on October 19, 2011, the Office of Thrift Supervision (OTS), whose powers included control over federal savings and credit associations, ceased to exist. Its functions were redistributed among other financial regulators.

The main federal laws on banking services include the Bank Holding Company Act of 1956, the International Banking Act of 1978, various securities laws that define the activities of banking institutions as issuers of securities and market participants (for example, the Securities Act of 1933 and the Stock Exchange Act of 1934; the Federal Deposit Insurance Act of 1950 [8].

A number of laws regulating financial activities have been amended. The most considerable of them included the following:

- The Glass-Steagall Act of 1933 that prohibited banks from joining dealers/underwriters of securities,

- The Foreign Bank Supervision Enhancement Act of 1991 that strengthened the control over non-US banks in the USA. The law was a part of the Federal Deposit Insurance Corporation Improvement Act of 1991.

- The 1999 Gramm-Leach-Bliley Act (GLBA) that allowed banks to join securities dealers and underwriters, insurance and other financial firms,

- The Sarbanes-Oxley Act of 2002 that tightened the requirements to corporate governance and reporting.

- The Dodd-Frank Act of 2009 (Dodd-Frank Act) that was adopted after the 2008 financial crisis. The law formalized many financial instruments to protect consumer rights, financial institutions and systemic protections. The CFPB was established under this law.

\subsubsection{Malaysia}

In Malaysia, there is a concept of "financial services or financial products". These terms were documented in the following Malaysian laws: The Exchange Control Act of 1953, the Banking and Financial Institutions Act of 1989, the Insurance Act of 1996, the Payment Systems Act of 2003, as well as Malaysian laws on Islamic finances: the Islamic Banking Act of 1983 and the Takaful Act of 1984. All of the above laws were abolished in June 2013 by two consolidated normative acts of Malaysia: The Financial Services Act of 2013 (FSA) and the Islamic Financial Services Act of 2013 (IFSA) [9]. According to Malaysian lawyers, new laws have been introduced to regulate and supervise financial institutions, payment systems and other relevant organizations, as well as to supervise the money market and the currency market of the country. Their main goal was to ensure financial stability of the country by strengthening safety and sustainability of financial institutes, integrity of the monetary and currency markets, and to protect consumers of financial services [10]. The Standards of Conducting Business are fixed in the norms of Appendix No. 7 to the Law of 2013. Any violation of these standards may cause a considerable fine (up to 10 million ringgit) or imprisonment.

\subsubsection{New Zealand}

Over the recent 5 years, the government of New Zealand has strived to create accessible and efficient systems for resolving disputes between consumers and financial services providers. All procedures for resolving disputes are completely free for consumers, and all expenses on financing the operation of centers for the alternative settlement of financial disputes are borne by financial services providers. However, not all financial disputes can be considered in an alternative way. Large financial disputes in the amount of more than NZD 200 thousand are subject to consideration by a state court or arbitration. The interrelations between financial services providers (banks, insurance companies, funds, etc.) and consumers are regulated by the New Zealand Financial Services (Registration and Dispute Resolution) Providers Act of 2008 (FSPA) that is in effect in the version of 2014 (the 2008 FSPA Act) [11]. The rights of consumers are protected by the Consumer NZ independent noncommercial organization established in 1959 [12]. This organization highly appreciated the changes to the above law made by the government in 2011. New Zealand authors emphasized that "the system of alternative resolution of financial disputes fixed in the 2008 FSPA Act meets the principles of the international dispute resolution practice. The latter includes a) Accessibility - Schemes are easily accessible to consumers, because each Scheme has its own website, b) Independence - financial services providers finance the activity of these Schemes, but they do not participate in administering Schemes or decision-making, c) Fairness - in each Scheme decisions are made on the basis of the information obtained by the staff of the Scheme (one of their main differences from resolving a dispute in the state court is that in case of the Scheme, the precedent system is not in effect, which allows mediators to consider each case individually and more flexibly, d) Accountability Schemes' Managers publish annual reports, the procedure for each Scheme is reviewed every five years, and e) Efficiency and effectiveness - the productivity and effectiveness of each Scheme are regularly studied, and statistical records are kept [13].

\subsubsection{Singapore}

Since the 1990s the Government of Singapore has been taking considerable efforts to promote alternative ways of resolving disputes, which is reflected both in the adoption of new legislation and in the establishment of new ADR centers. The parties of the dispute can relatively easily turn not to traditional litigation, but to alternative ways of resolving a dispute. In accordance with the Consumer Protection (Fair Trading) Act (CPFTA) [14] and the Consumer Protection (Fair Trading) (Regulated Financial Products and Services) Regulations 2009, certain consumers may use civil remedies for unfair practices, the conditions of which are harsh, oppressive or excessively one-sided. The procedure of providing financial products and services is also regulated by various industry standards and guidelines for the provision of banking and other financial services issued by the Association of Banks in Singapore (ABS) that unites 156 national and foreign banks, as well as by the Singapore Foreign Exchange Market Committee. The Committee has developed a Code of conduct, a Guide to Conduct \& Market Practices for Treasury Activities for currency market participants. The Association of Banks of Singapore, the Life Insurance Association of Singapore (LIA), and the General Insurance Association of Singapore (GIA) have similar codes of practice for financial 
transactions regulating the provision of financial products and services, as well as the procedure of dealing with consumer claims. Cl. 1, Art. 2 of the 2009 Regulation "On the Protection of Consumer Rights Regulating the Provision of Financial Products and Services" covers "financial products" and "financial services" included in the list of competences established for the Monetary Authority of Singapore ("MAS"). MAS-regulated financial products include any agreements, transactions and contracts provided by any person or financial institution controlled by the MAS. The list of these individuals and organizations is posted on the daily updated website of the Financial Institution Directory [15]. Article 6 of the above Regulation of 2009 fixes the "Specified dispute resolution scheme". This scheme is provided by the Financial Industry Disputes Resolution Center Ltd (FIDReC) that officially provides alternative resolution of disputes related to financial products or services regulated by the MAS between members of the FIDReC Center and consumers of financial services. It is necessary to note that all licensed financial institutions in Singapore must be members of FIDReC.

As a rule, all banks operating in Singapore should be members of the Deposit Insurance Scheme established under the Deposit Insurance and Policy Owners' Protection Schemes Act of 2011 as amended on 01.01.2017 that was developed to protect the rights of nonbank depositors. This group of investors can include individuals, companies and unincorporated organizations. They are protected by insuring the deposits of the bank's customers in Singapore dollars (SGD) kept in standard savings accounts, current and/or fixed deposit accounts for up to SGD 50,000 per each depositor.

\subsection{Special (nonjudicial) Authorities on Resolving Fi- nancial Disputes}

\subsubsection{USA}

The most famous, largest and most active consumer agency in the USA is the FTC [6]. The FTC has the Bureau of Consumer Protection [16]. The mission of the Bureau is to stop the unfair, fraudulent and deceptive methods of doing business. Until 2010, the Financial Practice Department of the Consumer Protection Bureau of the FTC was the only agency specifically authorized to protect consumers from fraud or fraudulent practices in financial services. All cases related to bank cards, mortgage lending practices and debt collection practices were under the responsibility of the Financial Practice Department of the FTC. Now these functions are performed jointly with the CFPB established in 2009 .

The mission of the CFPB is to protect consumers from dishonest, deceptive or offensive practices and to take actions against companies that violate the law. The CFPB was created as a single center for enforcing federal laws on consumer lending and consumer protection in the financial market [7]. Previously, these responsibilities were allocated among several agencies. The work of the CFPB includes the following: a) correction of unfair, deceptive, abusive practices or practices by preparing regulations, conducting supervisory campaigns and enforcing the law, b) enforcing laws that prohibit discrimination in consumer lending, c) receiving consumer complaints, d) raising the level of financial education, e) study of consumer experience related to using financial products, and (e) monitoring of financial markets to identify new risks to consumers [7]

In addition to the administrative quasijudicial procedure within the CFPB, a consumer complaint can be sent to the Financial Services Ombudsman [17]. The Office of the CFPB Ombudsman is an independent, impartial and confidential resource offering alternative dispute resolution within the framework of the CFPB. The CFPB Ombudsman acts confidentially and impartially. The Ombudsman's Office Charter determines the procedure for this authority's operation. The Charter includes such sections as the principles of the ombudsman, the office management scheme, access to information, as well as regular reporting. The Charter requires that the Office of the Ombudsman submits an annual report to the Director of the CFPB not later than on November 15. This report includes information on systemic problems considered during the reporting year, analysis of requests, description of advocacy, etc.

Established in 1933 after riots related to banks closure, the Federal Deposit Insurance Corporation (FDIC) is aimed at ensuring financial security for the US general public with the warranty that the individual savings will not disappear when a bank goes bankrupt [18]. The agency secures holdings in control and savings accounts in member banks that currently guarantee up to $\$ 100,000$ per person per bank and up to $\$ 250,000$ in pension accounts.

Undoubtedly, the protection of financial services consumers in the USA is not limited to the activities of the Financial Practice Department of the Consumer Protection Bureau of the US FTC, the CFPB, the Federal Deposit Insurance Corporation and other government agencies. Private agencies play an important role in protecting rights of financial services consumers. For example, FINRA, the US agency, is one of the first in the list of organizations providing services on arbitration and mediation of financial disputes [3,4]. FINRA is a large nongovernmental organization that supervises the activities of professional participants in the US securities market. FINRA members are US financial companies that deal with securities and are not controlled by other regulators, for example, financial brokers. FINRA is a self-regulatory organization financed at the expense of annual fees of its members, as well as accrued and collected penalties. FINRA was created through the consolidation of regulatory functions, execution and arbitrage of securities transactions by the Regulator of the New York Stock Exchange and the National Association of Securities Dealers. The merger was approved by the US Securities and Exchange Commission on July 26, 2007 [19]. FINRA manages the largest forum in the United States specifically established to contribute to the resolution of financial disputes among investors, securities firms and individual brokers. The FINRA Center for Alternative Dispute Resolution resolves more than $99 \%$ of financial disputes between brokers in the US securities market and their customers through a network of regional offices. FINRA provides arbitration and mediation services in more than 70 local offices, including at least one in all 50 US states, Puerto Rico and London. The FINRA list of financial specialists includes more than 6,400 arbitrators and about 250 mediators across the country. In 2016, FINRA had 3,681 cases, and resolved 3,635 cases.

Statistical data about the work of FINRA in 2016 are impressive. In addition to the central office, FINRA has other 16 offices in the USA and employs more than 3,500 specialists. Over the year, FINRA had identified and stopped more than 785 cases of fraud that were transferred to state courts for further investigation. Only in 2016 FINRA charged \$204.2 million as fines and restitutions. In 2016, FINRA members included 634,403 financial brokers and 3,784 financial institutions. The website of the organization says the following about the mission of FINRA: "Every investor in the USA relies only on one thing: the fairness of financial markets. Therefore, the mission of FINRA includes the following basic principles: 1) Protection of investors from fraud and bad investment practice. Every day, hundreds of professionally trained financial experts of FINRA are in the financial markets, carefully study brokers' activity, and pay thorough attention to the greatest risks for markets and investors". 2) The irrevocability of punishing rules violators. FINRA has experts, technologies and authorities to respond quickly to violations. If brokers violate the rules, the organization has the right to fine, suspend or prohibit their activities. Due to the aggressive vigilance of FINRA in 2016, 1,434 disciplinary actions were taken against registered individuals and companies, fines totaling $\$ 176.3$ million were imposed and restitutions were charged in the amount of $\$ 27.9$ million. 3) Detection and prevention of offenses in the US financial markets. FINRA uses the technology that is powerful enough to analyze markets and detect potential abuses. Using various methods of data collection, the organization works to detect cases of insider trading and any strategies firms or individuals use to obtain unfair advantages. In 
fact, FINRA handles an average of 37 to 75 billion transactions every day in order to form a unified picture of market trading in the United States. 4) Financial training of the population.

\subsubsection{Malaysia}

Today Malaysia has a whole system for alternative resolution of financial disputes. It includes various dispute resolution institutions that operate both for free (most) and on a paid basis. According to the Malaysian laws of 2013, the resolution of financial disputes is primarily the responsibility of the Ombudsman for Financial Services (OFS) [20]. Of course, parties can apply to a state court or arbitration to protect their rights and interests, but the OFS is explicitly specified in the above Malaysian laws of 2013 as the main body for resolving financial disputes. Previously, this authority was known as the Financial Mediation Bureau that had initially comprised 16 Islamic banks and financial institutions of the country, including the Bank Negara Malaysia. The bureau had been registered in 2004, and began its activity in 2005. The bureau was established on the initiative of the Bank Negara Malaysia (BNM) and was to become an authority for the alternative resolution of disputes between financial service providers and their customers. In 2015 only, almost 100 financial institutions licensed by the Bank Negara Malaysia became the Bureau members. Nowadays 28 commercial banks of Malaysia, 18 Islamic banks, 10 life insurance companies, 18 general insurance companies, 4 mixed insurance companies, 11 Islamic insurance companies, 6 financial institutions, 23 nonbanking institutions, 7 credit and bank cards operators, 30 Islamic insurance brokers (Takaful), and 26 financial advisers are members of OFS.

In 2015, the Bureau obtained 10,323 complaints from consumers of financial services, and considered and resolved 1,707 financial disputes [20]. As noted above, in 2013 the powers of the Financial Mediation Bureau were transferred to the OFS. According to Article 126.2 of the Law on Financial Services of 2013 and Article 138.2 of the Law on Islamic Financial Services of 2013, financial disputes should be considered according to the Financial Ombudsman Scheme [20]. The scheme of the financial ombudsman is approved by the Bank Negara Malaysia. Today the financial ombudsman scheme includes two stages of dispute settlement: 1) mediation; 2) quasijudicial proceedings (“Adjudication”). The competence of the OFS includes the settlement of the following types of disputes: 1) insurance disputes and disputes in the field of Islamic insurance (Takaful), and 2) disputes on banking services contracts and Islamic banks servicing contracts. The competence of the OFS is limited to the maximum price of the claim. It depends on the type of financial dispute. The total maximum amount of a claim the financial ombudsman is entitled to consider and resolve is 250,000 ringgit.

In addition to the financial ombudsman, the institutions that provide alternative dispute resolution services include: 1) Kuala Lumpur Court Mediation Center (KLCMC) [21], 2) Kuala Lumpur Regional Centre for Arbitration (KLRCA) [22], and 3) Securities Industry Dispute Resolution Center (SIDREC) [23].

\subsubsection{New Zealand}

The FSPA Law of 2008 established four schemes for resolving disputes between providers and consumers of financial services: 1) Banking Ombudsman (BOS), 2) the Insurance and Financial Services Ombudsman (IFSO), 3) The Financial Complaints Ltd company (FSCL), and 4) Financial Dispute Resolution (FDR) [24]. The fourth scheme for resolving disputes - Financial Dispute Resolution Service (FDRS) - will be considered in more details [25]. Currently, FDRS is an independent private company established to resolve disputes between consumers (citizens and small businesses) and financial service providers (financial institutions), and to provide financial advice. "FDRS is owned and operated by FairWay Resolution Limited. Since July 1, 2017, FairWay Resolution Limited has been an independent, employee-owned company that provides conflict management and dispute resolution services in New Zealand. FairWay employs about 100 specialists and has contracts with more than 110 analysts and dispute resolution specialists (adjudicators, reviewers, mediators and conciliators). Every year FairWay solves more than 14,000 disputes of all kinds and levels of complexity. Previously, FairWay had a Crownownership, and since July 1, 2017, the company has got private employee-ownership. The Financial Dispute Resolution Service (FDRS) is managed by FairWay, which makes it a part of New Zealand's largest alternative dispute settlement company. According to the results of the reporting for 2016-2017, FDRS members included 1,543 financial institutions in New Zealand. FDRS members act as defendants in financial disputes on applications of consumers of financial services (individuals and small business representatives.) According to the law, FDRS must publish names of all members registered in FDRS. The registration of a financial service provider as a member of the Financial Dispute Resolution Service (FDRS) is a prerequisite for the provision of financial services in New Zealand. The publication of the list of FDRS members allows the consumer of the financial service to verify that the financial service provider he or she intends to apply is registered as a FDRS member. However, the Government of New Zealand informed the public about several cases when companies attempted to register with the FDRS to impress consumers, but in fact they did not provide financial services listed on the FDRS website. The service for resolving financial disputes is not a state body and does not have the authority to enforce its decisions. Nevertheless, FDRS may terminate the membership of a financial service provider in FDRS if such member fails to comply with a FDRS decision on a dispute with a financial service consumer. The provider that does not belong to any Scheme is no longer entitled to provide financial services, and may be prosecuted by the Financial Markets Authority.

There are some limitations for the alternative resolution of financial disputes. FDRS may adjudge the applicant (the consumer of a financial service) "a compensation in the amount of not more than NZD 200 thousand". FDRS can accept complaints about the actions of financial service providers from individuals and small businesses. Small businesses are defined as enterprises employing 20 or less full-time employees. FDRS can also obtain complaints from larger organizations at its discretion. However, the applicant must be a retail client, not a wholesale client who got a financial service. FDRS will refuse to accept a complaint if the financial service consumer: a) has already filed a complaint with another alternative dispute resolution authority, b) if the complaint has already been considered by the ADR body and a decision on the dispute has been taken, c) if FDRS decides that the complaint is frivolous or vexatious, and d) if the complaint is not within the scope of FDRS. The procedure for resolving disputes by the FDRS Service is aimed at an efficient and fair resolution of the dispute. FDRS provides a three-step process for filing a complaint, which aims at an efficient and comprehensive resolution of the dispute. This scheme is paid by the industry participants, and it is free for consumers [26]. Stage 1. Before filing a complaint with the FDRS Service, the consumer should contact the employee of the Service by phone for advice on preparing the complaint. The Employee of the Service checks whether the financial service provider against whom the complaint is directed, is an FDRS member. Then the employee gives an explanation that the applicant should initially send the complaint to the financial services provider. If the provider cannot be contacted, the complaint is immediately sent to the settlement procedure. Stage $\mathbf{2}$ is to send the complaint to the financial services provider. If the applicant is not satisfied with the response, within two months as of getting the response from the financial service provider, the applicant can refer the dispute to the Service, rather than FDRS. Stage 3. The complaint can be filed to FDRS online, or by mail, or sent by fax. An FDRS employee can also help the applicant to make the complaint over the phone. After the beginning of the formal dispute resolution procedure (FDRS formal dispute resolution process), 
the FDRS Service Coordinator should contact the applicant (consumer) and the FDRS member (financial service provider) in order to try to resolve the dispute. The facilitator exchanges information that has been provided by all parties for everyone to be fully informed about the dispute. FDRS can initiate a formal mediation procedure under the control of the FDRS mediator. Usually this is done by phone, although it is also possible to use personal meetings and videoconferences. If the dispute cannot be resolved in mediation, the FDRS adjudicator makes the final decision "on the papers" with the recommended resolution. The applicant (the consumer of the financial service) has the right to recognize or not recognize the final decision of the FDRS Service. If the decision is recognized by the applicant, it becomes legally binding for the member of the FDRS (financial service provider) who must comply with all the conditions of the final decision. If the applicant does not recognize the decision of the FDRS Service, the dispute resolution procedure is considered complete. The consumer has the right to appeal to the state court [25].

The report on the activities of the FDRS Service in the fiscal 2016-17 year noted that 455 consumer complaints had been settled during the year, 230 of which had been agreed by the parties at the negotiation stage, before the official dispute resolution procedure by the FDRS Service. That year 236 new complaints were registered with the FDRS [27]. $73 \%$ of the total number of the consisted complaints were related to services of financial consultants or brokers, $13 \%$ - to services of creditors or nonbank deposits, and $12 \%$ - to services of other providers. 230 complaints were resolved in the course of negotiations prior to the beginning of the official dispute resolution procedure, 215 complaints were withdrawn, 6 complaints were resolved through mediation, and 4 complaints - by adjudication.

\subsubsection{Singapore}

The main authority for the alternative settlement of financial disputes in Singapore is the FIDReC [28]. The mission of FIDReC is to provide an affordable alternative, independent and impartial dispute resolution scheme to help consumers of financial services in resolving disputes with financial institutions in a friendly and fair manner without applying to court. The creation of such center was initiated by the financial sector to make dispute resolution more professional, transparent, and client-oriented. The FIDReC Center began its work on August 31, 2005, under the decision of the Director of the Monetary Authority of Singapore, Mr. Heng Swee Keat, who is the Minister of Finance of Singapore now. Today the FIDReC Center is the main institution of Singapore specializing in resolving financial disputes between financial services consumers and financial institutions. By June 2016, FIDReC had considered 8,300 disputes between consumers and financial institutions. Members of the FIDReC Center include 533 financial institutions in Singapore: banks, financial companies, life insurance companies, general insurers, comprehensive insurers, licensed capital market brokers, licensed financial advisors, and insurance intermediaries. FIDReC is an independent organization headed by the Council consisting of seven directors. The Chairman of the FIDReC Council is Mr. Goh Joon Seng, a former judge of the Supreme Court of Singapore. The Council ensures the independence, fairness, accessibility and transparency of the FIDReC dispute resolution. The FIDReC Center does not provide financial, legal or other professional consultations.

Over the 10 years of the Center's operation (as on June 2016), FIDReC had considered 8,300 disputes between consumers and financial institutions, including 5,567 through mediation and 2,733 as adjudication [29]. From July 1, 2015 to June 30, 2016 FIDReC had received 3,918 appeals containing 2,775 requests and 1,161 complaints. Dispute resolution in FIDReC is free of charge, except for an administrative fee in the amount of Singapore $\mathbf{\$} \$ 50$ that must be paid when applying. However, financial institutions (members of the Center) pay $\mathrm{S} \$ 500$ if the dispute reaches the adjudication stage. The competence of FIDReC includes considera- tion of disputes between consumers of financial services and financial institutions (members of the Center) in the amount of not more than $\mathrm{S} \$ 100$ thousand, and in case of disputes with banks not more than $\mathrm{S} \$ 50$ thousand. But in some cases FIDReC also considers disputes on higher amounts. In her study Lorna Tan, a Malaysian lawyer, noted that in 2007 FIDReC had considered an insurance dispute amounting to $\$ \$ 729$ thousand - the largest dispute in the history of the Center's operation. Limitation of the amount of the dispute transferred to FIDReC is related only to adjudication. The limitation is not applied to mediation. [30]. The dispute resolution procedure in FIDReC includes 2 stages. The first stage is mediation. After the registration, the consumer's application goes to the Case Manager. At this stage, the mediator of the Center helps the parties to settle the dispute in a friendly manner. If the parties do not come to an agreement, the dispute is transferred to the next stage. The second stage is a quasijudicial procedure (Adjudication). At this stage, the case is heard and considered by the quasijudge of the Center (Adjudicator), who is appointed from quasijudges. In difficult cases, the dispute may be resolved by a panel of judges.

\subsection{Training Population and Promoting the Protection of Rights of Financial Services Consumers}

\subsubsection{USA}

In order to achieve the goals on protecting consumers from unfair, deceptive or abusive financial practice, the CFPB has the right to create tools to increase consumer awareness of financial products and services that help consumers to take better financial decisions and make transactions that are most suitable for them. CFPB encourages financial education, publishes studies and informs financial companies about their responsibilities [7].

The FINRA nongovernmental agency also sets the goal to provide the population with financial education. According to FINRA, financial education is an important component of investor protection. FINRA provides investors with instruments and resources that can help them to make reasonable financial decisions. Investor Education FINRA Education Fund provides the resources required for financial success, and training investors to protect themselves from financial fraud. The FINRA.org website offers dozens of free resources on investing and preventing frauds, including online calculators and investor warnings. In addition, FINRA regularly conducts conferences and educational events where speakers inform about regulatory trends, FINRA priorities and practical recommendations on compliance with financial legislation. FINRA also carries out online training on specially developed FINRA online courses. FINRA Institute at Georgetown was established to train financial legislation and securities regulation to top managers of financial institutions [19].

\subsubsection{Malaysia}

The Bank Negara Malaysia (BNM) has issued a series of information pamphlets about banking products and services. These brochures are available in all branches of the bank throughout the country. They can also be downloaded from the Bank's website [31]. In addition, the bank website features samples of lawsuits related to the provision of banking and insurance services, as well as videos on such topics as "Using a credit card", "Buying a house", "Buying a car", etc.

\subsubsection{New Zealand}

The website of the New Zealand Consumer Council gives a detailed description of 4 schemes for resolving disputes between providers and consumers of financial services: 1) Bank Ombudsman (BOS), 2) the Insurance and Financial Services Ombudsman (IFSO), 3) the Financial Complaints Ltd company (FSCL), and 4) Alternative Financial Dispute Resolution (FDR). Each Scheme has 
its own website. In addition, all websites give samples of statements of claim. The Consumer Council also supports the Consumer Advice Line that is available for all consumers (except for middle and large businesses) on any issues related to consumer protection. Consultants can help each consumer to solve their problems, explain their rights in accordance with the legislation on consumer protection, and provide recommendations on any issues. The line operates though Monday to Friday. It is possible to contact consultants by phone or email.

\subsubsection{Singapore}

The basis for the resolution of financial disputes is set out on the website of the Monetary Authority of Singapore in the Dispute Resolution for Consumers brochure [32]. In 2003, a national financial education program (MoneySENSE) was established in Singapore. The program aims at helping consumers to become more confident in their financial affairs. The program helps consumers to acquire knowledge and skills to manage their finances, invest, plan their monetary needs, and exercise their rights as consumers of financial services. MoneySENSE is headed by the Financial Education Steering Committee (FESC). The MAS of Singapore is headed by the FESC. It comprises representatives from several government agencies and ministries, including the Ministry of Education (ME), the Ministry of Health Care (MHC), the Ministry of Labor (ML), the Ministry of Social Security (MSS), the Central Reserve Fund Committee (CPFB), the National Library Board (NLB), and the People's Association (PA). MoneySENSE also closely cooperates with various associations and organizations to reach different social strata. Volunteers and partners from higher education institutions, consumer and investment organizations, industry associations help financial education, and develop the content of classes, provide speakers, logistical and administrative support and other resources [33].

\section{Conclusion}

It is possible to conclude that by now the APAC countries (Malaysia, New Zealand, Singapore, and the United States) have formed complete systems for alternative settlement of financial disputes, including various dispute resolution institutions that act for free, as a rule. Schemes for resolving disputes are simple and understandable. Websites of the centers for resolving financial disputes contain pictures with all stages of the procedure. However, many experts note that the parties of financial disputes apply to state courts to resolve them, and alternative methods of dispute resolution are not popular. Such Malaysian authors as Umar A. Oseni, Adaweel Abideen Adeyemi, Nor Razin Mohammed Zain [34], and American author Aida Maita [35] et al. wrote about it. That is why the governments of the APAC countries have to make considerable efforts to promote the advantages of alternative methods of financial disputes resolution in order to change the current practice and prejudice.

\section{Acknowledgements}

The study was financially supported by the RFBR within the framework of scientific project No 17-03-00093 "a" (N.E. Frolova).

\section{References}

[1] Dudin MN, Sekerin VD, Smirnova OO, Sepiashvili EN (2014), State anti-crisis management of banking sector: looking for optimization ways and contemporary development trends. Journal of Advanced Research in Law and Economics, 5(2), 74-81.

[2] Dudin MN, Senin AS, Frolova EE, Abashidze AKh, Rusakova EP (2017), The role of the economic and mathematical modeling in the sustainable development of the foreign trade policy of modern countries.
International Journal of Applied Business and Economic Research, 15(8), 43-51.

[3] Abu-Manneh R, Hot Topics Affecting the Financial Services Industry. Mayer Brown. https://www.mayerbrown.com/Hot-Topics-Affectingthe-Financial-Services-Industry-09-28-2015/

[4] Speller D, Hornyold-Strickland F, International arbitration in the $\mathrm{fi}$ nance sector: Room to grow? CDR. https://www.cdrnews.com/categories/arbitration-and-adr/7122-international-arbitrationin-the-finance-sector-room-to-grow

[5] Malbon J, Institutional Structures Relating to the Administration and Enforcement of Consumer Laws. Australian Consumer Law. http://consumerlaw.gov.au/files/2016/05/ACL_Comparative-analysisoverseas-consumer-policy-frameworks_Part5-1.pdf

[6] Federal Trade Commission (FTR). https://www.ftc.gov/

[7] Consumer Financial Protection Bureau https://www.consumerfinance.gov/

[8] Lustgarten I, Banking regulation in the United States: overview. Practical Law. https://uk.practicallaw.thomsonreuters.com/w-0077945 ?transition Type $=$ Default \&contextData $=($ sc.Default $) \&$ firstPage $=$ tru e\&bhcp $=1 \&$ comp $=$ pluk. Revised March 30, 2017. Accessed August 10 2018

[9] Financial Services Act 2013 (FSA 2013). e-Federal Gazette. http://www.federalgazette.agc.gov.my/outputaktap/20130322_758_BI_ ACT\%20758.pdf

[10] Fen A, Tsin S, Malaysia's new financial services regulatory framework. Financier Woldwide. https://www.financierworldwide.com/malaysiasnew-financial-services-regulatory-framework/\#.W21kROgzbIV

[11] Financial Service Providers (Registration and Dispute Resolution) Act 2008, (FSPA 2008). New Zealand Legislation. http://www.legislation.govt.nz/act/public/2008/0097/latest/DLM110942 7.html. Accessed August 10, 2018.

[12] Consumer. https://www.consumer.org.nz/

[13] Case Studies. Insurance \& Financial Services Ombudsman Scheme. https://www.ifso.nz/case-studies/

[14] Consumer Protection (Fair Trading) (Regulated Financial Products and Services) Regulations 2009 (CPR 2009). Singapore Statutes Online. https://sso.agc.gov.sg/SL/CPFTA2003-S64-2009?DocDate=20170104

[15] Types of Institutions. Monetary Authority of Singapore. http://www.mas.gov.sg/singapore-financial-centre/types-ofinstitutions.aspx

[16] Federal Trade Commission. BCP of FTC (2018). https://www.ftc.gov/

[17] CFPB Ombudsman. Consumer Financial Protection Bureau. https://www.consumerfinance.gov/cfpb-ombudsman/

[18] Teslik L, The U.S. Financial Regulatory System. Council on Foreign Relations. https://www.cfr.org/backgrounder/us-financial-regulatorysystem

[19] Financial Industry Regulatory Authority. FINRA (2018). http://www.finra.org/industry/2018-finra-annual-conference

[20] Scope. Ombudsman for Financial Services. https://www.ofs.org.my/en/scope. Accessed August 10, 2018.

[21] Kuala Lumpur Court Mediation Centre (KLCMC). ASEAN Law Association. http://www.aseanlawassociation.org/11GAdocs/workshop5malaysia.pdf. Accessed August 10, 2018.

[22] Kuala Lumpur Regional Centre for Arbitration (KLRCA) https://klrca.org/. Accessed August 10, 2018.

[23] Securities Industry Dispute Resolution Centre (SIDReC). https://sidrec.com.my/

[24] Financial dispute resolution: The schemes. Consumer. https://www.consumer.org.nz/articles/financial-disputesresolution\#article-the-schemes

[25] Financial Dispute Resolution Service (FDRS). https://fdrs.org.nz/

[26] Mitchell J, Financial dispute service trying to boost profile. RNZ. https://www.radionz.co.nz/news/business/307021/financial-disputeservice-trying-to-boost-profile

[27] Financial Dispute Resolution Service Annual Report 2016-2017. Financial Dispute Resolution https://fdrs.org.nz/assets/Uploads/459098f444/FDRS-Annual-ReportFINAL-27-Sept-2017.pdf

[28] Financial Industry Disputes Resolution Centre Ltd (FIDReC). https://www.fidrec.com.sg/website/index.html

[29] Summary of FIDReC Annual Report 2015/2016. Financial Industry Disputes Resolution Centre Ltd https://www.fidrec.com.sg/website/annualreports/Summary\%20of\%20F IDReC\%20Annual\%20Report\%202015-16.pdf

[30] Tan L, Enhanced disclosure good for financial dispute resolutions. The Straits Times. https://www.straitstimes.com/opinion/enhanceddisclosure-good-for-financial-dispute-resolutions

[31] Bank Negara Malaysia (BNM). http://www.bnm.gov.my/

[32] Getting it Right: How to Resolve a Problem with Your Financial Institution. Monetary Authority of Singapore http://www.mas.gov.sg/ /media/Moneysense/DisputeResolutionGuide.p df

[33] MoneySENSE. http://www.moneysense.gov.sg/AboutMoneySENSE.aspx. 
[34] Osen U, Adeyemi F, Zain N (2016), Customers' perceptions on the dispute resolution clauses in Islamic finance contracts in Malaysia. Review of Financial Economics, 31, 89-98.

[35] Maita A (2014), Arbitration of Islamic Financial Disputes. Annual Sur vey of International \& Comparative Law, 20(1) https://digitalcommons.law.ggu.edu/cgi/viewcontent.cgi?referer=\&https redir $=1 \&$ article $=1183 \&$ context $=$ annlsurvey 